Nikolas Gunn*

\title{
Translating the Gospel in Viking Age England: The Evidence from Two Old Norse Loan Translations from Old English
}

https://doi.org/10.1515/ang-2019-0052

Abstract: A recent resurgence of interest in Old Norse linguistic borrowings in Old English has greatly expanded our knowledge of the contact situation between these two speech communities in the early medieval period and beyond. However, there are a significant number of words that have been considered borrowings in the "other" direction, i.e. from Old English to Old Norse, which have not attracted the same amount of attention in current scholarship. Much of this material requires reassessment and this paper provides a case study of two parallel compound formations in both languages - OE bærsynnig [mann]/ON bersynðugr [maðr] ('one who is openly sinful; publican'), and OE healsbōc/ON hálsbók ('phylactery, amulet', lit. 'neck-book') - that have traditionally been considered loan translations from Old English to Old Norse with little evidence other than their formation from cognate elements. In the absence of clear-cut linguistic criteria for identifying loan translations between these two closely related languages, this paper draws on a range of literary evidence to argue for a strong likelihood of a relationship between the two compounds. Both words offer important evidence for biblical translation practices, and contribute to our knowledge about the Christianisation of Norse speaking peoples and Anglo-Norse language contact in Viking Age England.

\section{Introduction}

The study of early medieval Anglo-Norse cultural contact is a fraught area, particularly where notions of 'influence' or 'borrowing' are concerned. Whether analysing connections between vocabulary, literary topoi or art styles, scholars are faced with a problem that has been mentioned many times before, but has been put most succinctly by Roberta Frank (2007: 30): "rarely can the borrower be distinguished from the lender". While linguists might be able to rely on the relatively 'secure' evidence

Corresponding author: Nikolas Gunn, Pembroke College, Oxford

E-Mail: nikolas.gunn@ell.ox.ac.uk 
of formal morpho-phonological criteria to assess whether a word has been borrowed from one language to the other, this sort of evidence remains relatively rare: it is simply the case that there is a large number of purportedly borrowed lexical items that could quite easily have originated in either Old English or Old Norse. ${ }^{1}$ This article presents case-studies of two parallel compound words in both languages - ON bersynðugr [maðr] 'sinful [man]' (OE bærsynnig [mann], 'publican') and hálsbók 'neck-book; amulet' (OE healsbōc 'phylactery, amulet') ${ }^{2}$ - that exemplify some of the methodological problems that philologists encounter when trying to unpick routes of lexical borrowing between languages, and even if there can be said to be any lending in the first place. There are two crucial things about both compounds: first, that they are part of a modest group of words that have been suggested as borrowings from Old English into Old Norse, a relatively understudied aspect of Anglo-Scandinavian contact, and second, that the Old English words are specifically associated with gospel translations in early medieval England. These words are potentially of great value in understanding aspects of the Christianisation of the Norse speaking peoples in Viking Age England, and specifically how churchmen may have dealt with the communication of specifically Christian cultural concepts. In lieu of formal morpho-phonological criteria, the examination of the individual words in their context - taking into account etymology, translation practice and (where relevant) spelling - paired with judicious use of relevant literary evidence, is used to reconstruct a plausible case for borrowing. In connection with this, I posit that our obsession with establishing clear-cut 'directions' of linguistic borrowing in this particular contact situation might disguise an altogether more complex reality, and that the ambiguity of many cases should in fact form a central part of our interpretation.

The article is divided into four parts. In the first section (2), I briefly survey the current scholarly landscape in the field of Anglo-Norse language contact, noting that there is a relative lack of interest in Old English influence on Old Norse, and provide a note on loanword terminology. The following section (3) constitutes case studies of the compounds themselves, examining the linguistic and literary

1 For example, Pons-Sanz (2013) has urged caution in the identification of Old Norse loans in Old English, including words that have often been seen as being 'clear-cut' borrowings such as lagu 'law' (ON lágr) (84), saclēas 'innocent' (ON saklauss) (101) and hāmsōcn 'offence of attacking a man in his own house' (ON heimsókn) (116), and suggesting that we cannot categorically discount native derivation. In the context of Old English words in Old Norse, words such as guðsif(jar) 'spiritual relationship; sponsorship' (OE godsibb) (189-194) and húsl 'the Eucharist' (OE hūsel) offer similar problems (see the general discussion in Gunn 2017: 229-233).

2 Cleasby-Vigfússon s.v. bersynðugr, which also gives the definition 'publicans and sinners'; Ordbog over det norrøne prosasprog s.v. bersynðugr; DOE s.v. bær-synnig; Cleasby-Vigfússon s.v. hálsbók; DOE s.v. healsbōc. 
evidence for bærsynnig/bersynðugr and healsbōc/hálsbók, drawing on a range of patristic and early medieval sources. In Section 4 I propose a Viking Age context for the transmission of both these words from Old English to Old Norse and give some thoughts on our current treatment of linguistic parallels between the two languages. Finally, a brief conclusion offers some possible avenues for further research (Section 5).

\section{Old English Borrowings in Old Norse: A Brief Overview}

\subsection{Recent Developments}

In the past couple of decades there has been something of a renaissance in the study of Anglo-Norse language contact. ${ }^{3}$ In particular, Richard Dance (2003, 2019), Angelika Lutz (2013, 2017) and Sara Pons-Sanz (2000, 2013) have together updated our understanding of Old Norse borrowings in Old and Middle English, eschewing the earlier tendency to treat lexical borrowings in isolation from contextual and stylistic considerations. Each of these scholars have emphasised the need for greater caution in our treatment of loans, a point that I will return to at the end of the present article. Despite this resurgence in interest, there has been a relative lack of attention to the issue of borrowing in the "other" direction - that is from Old English to Old Norse.

This relative dearth of scholarship on English loans in Old Norse is not without good reason however: it is a simple fact that, compared to Norse loans in English, there are fewer verifiable borrowings the other way around. Most scholars that have engaged with the topic have been almost entirely dependent on Absalon Taranger's 1890 monograph, Den Angelsaksiske Kirkes Indflydelse paa den Norske, a work that is still of considerable use to linguists and literary historians. Taranger's discussion of English borrowings starts with the a priori assumption that Anglo-Saxon churchmen were the main players in the conversion of the Norse speaking peoples, despite the vital role of the continental and Irish churches in the process. Thus even commonplace lexical items like prestr or kirkja are linked confidently to the influence of English speakers. ${ }^{4}$ Later studies of these

3 Notably in the ongoing work of the Gersum Project: <https://www.gersum.org/>.

4 It is entirely possible that these, and much other Old Norse core lexis relating to Christianity, could have arrived via contact with speakers of other Germanic languages or, indeed, speakers of Romance languages. Often it is nearly impossible to ascribe a single source language with confi- 
borrowings largely integrated them into studies of loanwords in Old Norse in general, more often than not presenting Taranger's suggestions with little challenge or expansion. ${ }^{5}$ Although we still await a wide-ranging update of Taranger's arguments and data, ${ }^{6}$ Gammeltoft and Holck's 2007 case study of OE gimstān in an Old Danish text included some provisional suggestions for reorganising the material in the context of eastern dialects of the North Germanic languages, but more importantly demonstrated the value of intensive close work on individual lexical items.

By contrast, there has been significant recent research on possible literary connections and textual exchange between England and Scandinavia in the late Viking Age, especially with regards to English influence on early Old Norse literature. For the purposes of the present article, the expansion of interest beyond the traditional focus on poetry in general (and heroic literature in particular) has been an especially significant development. ${ }^{7}$ Building on the foundations laid by Arnold R. Taylor's (1969) work on the Norse version of Ælfric's De falsis diis, Christopher Abram's $(2004,2007)$ research has established beyond doubt that vernacular homiletic material was exchanged between English and Norse speakers, and that some of it was actively translated from Old English into Old Norse. ${ }^{8}$ As well as bolstering the notion that England remained "one of the most important conduits" for the transmission of Christianity to Scandinavia, Abram (2004: 2223, 2007: 443-444) also points to the tantalising possibility of Anglo-Scandinavian textual communities in England into the twelfth century. When set alongside research by Pons-Sanz (2007) and Kari Ellen Gade (2007) focusing on loan translations between Old Norse and Old English in 'learned' Christian contexts, there is

dence. For example, a word like ON prestr 'priest' could in theory have come from OE prē (o)st, Old High German priester/priestar, Old Saxon prēstar/prēster or one of the various Romance reflexes of Latin presbyter (e.g. Anglo-Norman preste) (see the forms under OED s.v. priest, n.; see also the discussion of ON prestr/OE prē(o)st in Gunn (2017: 113-115 and 220-225)).

5 The most important works include Fischer (1909), Falk and Torp (1910), Höfler (1931, 1932), Carr (1939) and de Vries (1955). Höfler, in particular, tends to settle on continental Germanic source languages for many of the loanwords that Taranger would have ascribed an Old English origin. Hofmann (1955) also examined lexical exchange between Old English and Old Norse, though this was subsumed under his interest in literary exchange in general. Thors (1955), despite his focus on Old Swedish, also considers Old Norse evidence.

6 The two attempts at updating Taranger in the past century remain unpublished: Buse (1955) and Gunn (2017), though the latter is currently in the process of being turned into a monograph.

7 On the poetic material, see especially: Hofmann (1957), McKinnell (1990-1993, 2001), Townend (2002, 2005, 2011) and Poole (2013).

8 Taylor's work has recently been directly updated by John Frankis (2016) and the Old Norse sermon's fourteenth-century intellectual and material context has been discussed in detail by Wellendorf (2018: 43-70). See also the survey in Hall (2000). 
significant space to consider possible borrowed linguistic material in early Old Norse texts in general, particularly in Norway and Iceland where we have evidence from the twelfth century onwards.

\subsection{A Note on Terminology}

It is worth briefly discussing some of the linguistic metalanguage surrounding the study of lexical borrowing for the benefit of readers. The term 'loanword' is used to describe words that have come into a language's lexicon as a result of borrowing from another language (Haspelmath 2009: 36). In a classic article, Einar Haugen (1950: 215-216) suggested that the term loanword should be used only to describe "morphemic importation without substitution", or in other words the borrowing of a word without any change to its morphological structure (though more often than not loanwords are adapted to the native inflectional system). These are rare in the case of Old English loanwords in Old Norse, but one good example is OE tācn 'token, sign; miracle', which was borrowed as ON tákn 'miracle' (cf. native ON teikn). ${ }^{9}$ A key concept for the present article is that of loan translation (or calquing), whereby the underlying linguistic structure of a word is analysed and translated word for word and/or morpheme for morpheme (Haspelmath 2009: 39); in the context of exchange between Old English and Old Norse, such words are often compounds. For example, Old English lèodbisc(e)op '(suffragan) bishop' was translated into Old Norse as lýðbyskup, with OE lēod 'people' translated into the equivalent ON lýðr 'people' and OE bisc(e)op 'bishop' rendered with ON byskup. ${ }^{10}$ Closely related to loan translations are loan renditions, whereby part of a target word is translated into a formal equivalent in the native language, but at least one part is not. Kastovsky (1992: 315) uses the example of Latin nocturnale and OE nihtsang, with the Old English compound showing recognition that part of the Latin word is derived from nox 'night', but joins it with the headword sang 'song', which has no parallel in morphology of the Latin word. Throughout I use the terms 'borrowing' or 'loan' to refer to all borrowed linguistic material in general, whether a loanword, loan translation or loan rendition.

9 Bosworth-Toller s.v. tācn; ONP s.v. tákn; see the etymology in Íslensk orðsifjabók s.v. tákn. 10 Bosworth-Toller s.v. lēodbiscop; Cleasby-Vigfússon s.v. lýðbyskup. 


\section{Word Case Studies}

The two words that form the focus of the present article were together mentioned by Charles T. Carr (1939: 31-37) in his book Nominal Compounds in Germanic, specifically in a section dealing with parallel compound formations in various Germanic languages. ${ }^{11}$ However, neither word was afforded much by way of accompanying explicatory material and the textual sources for both were also elided. Of OE bærsynnig, Carr (1939: 33) notes only that it is used "in Biblical texts translating publicanus", yet it turns out that the word occurs exclusively in the tenth-century glosses to the Lindisfarne and Rushworth Gospels (DOE s.v. bær-synnig, 'publican [lit. 'openly sinful']'). ON bersynðugr, on the other hand, is first attested in a twelfth-century translation of one of Gregory the Great's gospel homilies. ${ }^{12} \mathrm{OE}$ healsbōc, which Carr (1939: 35) defines as an 'amulet', appears only in the West Saxon translations of the Gospels, with the equivalent ON term hálsbók being attested in the Icelandic law-code Grágás and a section of Boglunga saga (see DOE s. v. heals-bōc; ONP s.v. hálsbók). The fact that both English words are specialist biblical terms connected exclusively with different traditions of translating the gospels in early medieval England is particularly important to what follows, and indeed I am as interested in Old English translation from Latin as I am in how the terms may have been transmitted to a Scandinavian context.

This leads to a few important methodological points that are worth highlighting at the outset. First, any treatment of these words has to take into account the place of Latin and the different traditions of vernacular biblical translation in England, something that will inevitably cause complications in establishing a neat line of influence from Old English to Old Norse (or vice versa). As will be explained in the sections to follow, while we have a relatively good picture of the community of St Cuthbert where the Lindisfarne Gospels were glossed, we have comparatively little idea about the genesis of the West Saxon translation of the Gospels or for whom they were intended, despite the modest number of surviving manuscripts (Liuzza 1998: 6-7). Any supposed connection between the Old English and Old Norse words therefore has to rely on our general knowledge of the linguistic communities of late Viking Age England in order to posit a context in which loans may have been transmitted. The second point is that we have to deal with the fact that there is a significant gap between the first record of these words in Old English and their later material appearance in Old Norse. This is closely

11 Carr's work remains very useful, and much of his data would be worth revisiting.

12 All first attestations are based on data from the relevant $O N P$ entries. While this does not guarantee a secure first date, it is as close as we are able to get with current electronic resources. 
intertwined with the third and final point, which is the remit of medieval loanword studies in general; Dance (2003: 8), for example, in discussing the work of twentieth-century scholars working on Old Norse borrowings in English has suggested that

[their] analyses tend, perhaps inevitably, to involve a greater fascination with the NorseEnglish contact situation itself, with the means by which Norse derived material can be said to have penetrated English and what this might tell us about the social and linguistic circumstances at the time, than with those features that stand as the evidence for contact in the first place.

As mentioned above, recent research in the area has taken care to focus on stylistic analysis of assimilated Old Norse lexis within English itself, ideally in the context of coherent and localisable corpora of texts (Dance 2003: 9), and thus moving away from attempts to reconstruct earlier contact situations, though this is not to say that recent scholarship has had nothing to say on this subject (see especially Lutz 2013 on prestige). Given the paucity of evidence for Old English borrowings in Old Norse in general, plus the difficulties of localising Norse material - we are lucky if we are able to assign a text to Iceland or Norway, let alone a more specific region -, borrowings by necessity have to be treated in a more isolated manner. I view considered reconstruction of a context for contact as a legitimate and enlightening end in and of itself, especially since we understand little of the contact situation in Viking Age England in general. ${ }^{13}$

Finally, it is worth restating the point made at the outset of this article: given the close genetic relationship between Old English and Old Norse, we need to distinguish carefully between an "actual connection" and "coincidence", and ultimately the problem of demonstrating connections "at the level of detail necessary to convince" (Dance 2004: 2). This is ultimately impossible, barring 'safe' linguistic evidence, and scholars like Matthew Townend have demonstrated the merit of building careful contexts for borrowing and interaction between English and Norse speakers using literary evidence where linguistic data is lacking. ${ }^{14}$ The present article follows this tradition.

13 Something that Lesley Abrams $(1995,2000)$ has discussed and grappled with in detail from a historical perspective.

14 See especially his 2002 book Language and History in Viking Age England. 


\subsection{Barefaced Sinners: OE bærsynnig - ON bersynðugr}

\subsubsection{OE bærsynnig and its Context}

The Old English word bærsynnig is attested around thirty times in the Dictionary of Old English Corpus (DOEC), though its use is entirely restricted to the glosses to the Lindisfarne and Rushworth Gospels. The Dictionary of Old English (DOE) offers the definition "publican, tax-collector, literally '[one who is] openly sinful”, , as well as in "collocations suggesting the barefaced sinfulness of publicans" (DOE s.v. bærsynnig), and indeed the example entries demonstrate that it is, among other things, found collocated alongside words such as synfull 'sinful', æ̋swica 'deceiver, seducer' and portcwēn 'prostitute'. ${ }^{15}$ The word is an adjectival compound made up of $\mathrm{OE}$ bær 'naked [including figurative meanings]' (DOE s.v.) and synnig 'sinful, wicked' (Bosworth-Toller s.v.), but is used substantively in almost every instance (with one exception, to which I will return below). It exclusively glosses Latin publicanus 'publican, tax-collector', the Roman administrative officials who appear frequently in gospel accounts of Christ's ministry, ${ }^{16}$ and a word that itself appears often in collocation with the more general peccator. The glossator Aldred always translates both terms separately, as in the following example from Luke 15:1:

Woeron ða geneolecdon him bær-synnigo 7 synnfullo pte geherdon hine gehyrston 1 [pharisaei] 7 uð-uto cuoeðendo pte ðes ða synnfullo onfoeð 7 etað mið him (Skeat 18711887: 153).

Erant autem adpropinquantes ei publicani et peccatores ut audirent illum, et murmurabant Pharisaei et scribae, dicentes quia "Hic peccatores recipitet manducat cum illis" (Kinney 2013: 402).

'Now the publicans and sinners came to him so that they could hear him. And the Pharisees and the scribes grumbled, saying: this man takes in sinners and eats with them'. ${ }^{17}$

Aldred is careful to provide a gloss for nearly all instances of the Latin word, with Patrizia Lendinara (2016: 352-353) noting he omits it only four times when it denotes named figures like the apostle Matthew or Zacchaeus, and the word does not vary with other synonyms as much as it does for pharisaeus. In the Rushworth gloss, forms of bærsynnig are restricted to the glossator Owun's portion (which

15 Bosworth-Toller s.v.synfull; DOE s.v. æeswica; Bosworth-Toller s.v. port-cwēn. The latter of these has traditionally been linked to ON portkona 'prostitute' (Cleasby-Vigfússon s.v.port-kona; the ONP does not supply a definition).

16 By my count the various forms of the lexeme publicanus occur 22 times in the Vulgate.

17 All translations are my own unless stated otherwise. 
consisted of Luke, John and part of Mark), a man whose language is usually considered to represent a northern dialect and who seems to have used Aldred's gloss as a guide (Tamoto 2013: cii; for a brief overview of the dialects of the glossators, see ibid. $\mathrm{xxx}-\mathrm{xxxii})$. It seems likely that the compound is therefore a specifically Northumbrian coinage, perhaps originating at the religious community of St Cuthbert at Chester-le-Street, where Aldred was based.

Aldred shows a sensitivity to the underlying etymology of the Latin word that we should expect from an educated English speaker in the tenth century, with Karen Jolly (2016: 363) going so far as to characterise him as being "quite literally a philologist”. Key to both Latin and vernacular glossing traditions in the early medieval period was an understanding that detailed analysis of a word's etymology would allow excavation of the "true sense of a word" (Kornexl 2003: 206). It is clear that, when it comes to glossing publicanus, the formation of the compound bærsynnig had been guided by traditional patristic scholarship that saw etymological study as a way of uncovering underlying moral meaning. Isidore of Seville's Etymologiae was almost certainly one of the main guides for explicating both the particular cultural role of the publicans in the Roman Empire and the etymology of the word publicanus:

Publicani appellantur conductores vectigalium fisci, vel rerum publicarum, sive qui vectigalia publica exigunt, vel qui per negotia saeculi lucra sectantur. Unde et cognominati sunt (Lindsay 1911: IX.iv.32). ${ }^{18}$

'Publican is the title given to the tax officials of the imperial treasury, or public matters, or those who extract public taxes, or those who seek profit through worldly business. And thus they are named'.

Isidore notes the relationship between publicanus and the adjective publicus, a word with three primary interrelated senses, including 'of, affecting, or available to the whole community or the state, public', 'authorised, sanctioned, or maintained by the state or the whole community', and the more general 'easily discerned, perceived, or seen by all, open, manifest' (DMLBS s.v. publicus). Indeed, in his own interpretation of publicanus, Isidore extends the meaning of the word from a specific cultural referent (i.e. the tax collectors, who affect a whole community) to a generalised sense that includes anyone who seeks to extract profit via negotia saeculi, 'worldly gain'. It is this sense of 'open, manifest' that the compound bærsynnig taps into, with the qualifying element bær being limited to that particular meaning (in

18 Book X of the Etymologiae also discusses the word publicanus, notably right before the word peccator; see Lindsay (1911: X.227). 
addition to 'naked') in Old English..$^{19}$ Its joining with synnig means that the resultant formation is a loan rendition rather than a translation, though it certainly translates the theological fact that the publicans were seen as wicked.

While OE bærsynnig therefore engages with the etymology of the word publicanus, this does not completely explain why this particular formation should be preferred. Certainly there were other options for glossing publicanus in such a way that communicated its specific meaning in the context of the culture of Roman Judaea; Farman, the Mercian glossator of the Rushworth Gospel, for example, uses gafolgerēfa 'tax-gatherer' on four occasions (including once directly with reference to Matthew himself), which might seem a more programmatically 'faithful' translation from a modern point of view (see DOE s.v. gafol-gerēfa). However, Aldred is not alone in this particular translation tradition: the Rushworth gloss, which is less uniform in its rendering of publicanus in general, also has three instances of the form eawisfiren ('publican, tax-collector; public sinner') in Farman's portion, which is formed from ææwisc 'shameless' and firen 'wicked deed, sin, crime', while the tenth-century Cleopatra Glossary includes the analogous form ææwiscfireniend. ${ }^{20}$ However, outside the Cleopatra Glossary, the explicit reference to 'manifest' sinning is not really known in the West Saxon tradition; the $D O E$ entries for both bærsynnig and gafolgerēfa note a Southumbrian preference for the more general mānfull 'evil, wicked' in every instance.

There was, with a few exceptions, an established tradition in Old English of representing the publicans as simply being 'sinful' or 'wicked', elevating the moral problems of their status in Judaean society even as the specific details of their profession are obscured..$^{21}$ This seems to have its ultimate root in the exegesis of St Jerome and his commentary on Matthew, and particularly in his discussion of chapter 18:17:

Quando autem dicitur: Sit tibi sicut ethnicus et publicanus, ostenditur maioris esse detestationis qui sub nomine fidelis agat opera infidelium quam hi qui aperte gentiles sunt. Publicani enim uocantur secundum tropologiam qui saeculi sectantur lucra et exigunt uectigalia per negotiationes et fraudes ac furta, scelera atque periuria (Hurst and Adriaen 1969: 161).

'When it is said: he will be to you as though a pagan or publican, it is revealed that he who is named a believer but does the works of the unfaithful is more damned than those who are openly gentiles. For they are called publicans as a tropologia, those who pursue worldly profit and weigh their gains through business and fraud, thievery, wickedness and false oaths'.

19 The DOE notes that bær is used to gloss the words apertus 'plain', manifestus 'evident' and nudus 'naked; plain'.

20 DOE s.v. éawis-firen; $D O E$ s.v. firen; $D O E$ s.v. æ̋wisc-fireniend.

21 It is also worth comparing the Old Saxon Hêliand, which avoids loan translations of pharisaeus and publicanus, opting for more general epithets such as fiund 'enemy'. 
The key word here is tropologia, which refers to figurative interpretative discourse, particularly where Scripture and its 'moral meaning' are concerned (see $D M L B S$ s.v. tropologia 1.). Jerome condemns the pursuit of worldly profit by both deceptive (fraud, false oaths) and flagrant (business, thievery, general wickedness) means. This point is refined further in his exegesis of the Parable of the Two Sons (Mt 21:28-32), where he states that the first son represents the gentiles (and by extension the publicani et meretrices) who, despite initially committing evil openly, eventually turn to Christ, while the second son represents the Pharisees who actively and willingly disobeyed God despite his revelations (Hurst and Adriaen 1969: 193-195). In coining the loan rendition bærsynnig, Aldred - or at least the Northumbrian tradition he was working in - demonstrates not only sensitive linguistic analysis of the Latin publicanus, but also incorporates and condenses a body of exegetical tradition as well (Stanton 2002: 9).

\subsubsection{ON bersynðugr and its Context}

I now turn to the Old Norse word, that is bersynðugr, which is formed of directly cognate elements to the Old English term. ${ }^{22}$ The ONP gives the meaning 'notorisk syndig, helt og aldeles syndig' ('notoriously sinful, completely and utterly sinful'), though the adverbs notorisk, helt and aldeles are rather odd choices given that the entry for berr does not list any of these senses, instead giving definitions analogous to those for the equivalent Old English word. We find both literal senses like 'bar, nøgen, udækket' ('bare, naked, uncovered') and figurative senses like ‘åben, åbenlys, umiskendelig, klar' ('open, evident, manifest, clear'), but nothing with a meaning akin to 'notorious' or 'complete'; for this reason I argue that the compound should be interpreted more along the lines of the Old English word, i.e. 'openly or manifestly sinful' (see also below, note 29, where parallel adjectival compounds with ber- largely support this meaning). Cleasby-Vigfússon gives the definition 'a sinner', adding also the phrase 'publicans and sinners' alongside the Latin publicani et peccatores (with justification, as we will see below). ${ }^{23}$ In addition to Carr's very brief mention of it in his own work (1939: 33), the word has been discussed briefly by Ernst Walter on two separate occasions (1976: 88-89 and 1986: 299). Accounting for its use, Walter (1986: 299) suggests that, since the profession of the publicans was unknown in Scandinavia, this compound formation simply needed to communicate that "die publicani waren [...]

22 ONP s.v. berr; ONP s.v. synðugr 'syndig, syndefuld, etc.' ('sinful').

23 ONP s.v. bersynðugr; Cleasby-Vigfússon s.v. bersyndugr. 
offenkundige oder ganz schlimme Sünder" ('the publicani were [...] flagrant or very wicked sinners'). ${ }^{24}$ The earliest manuscript attestation of bersynðugr listed in the ONP is in the thirteenth-century manuscript AM 677 4to, and specifically in an Old Norse translation of the thirty-fourth of Gregory the Great's gospel homilies on Luke 15.1-10, a hugely influential and popular collection throughout the medieval period. On the basis of philological comparison between AM 677 4to and the Norwegian Homily Book, Didrik Arup Seip (1949: 28-29) argued that the work is almost certainly a copy of an original translation from the early twelfth century. Below are a couple of examples in context:

Berfvndgr men como til Ihm ad hevra orp hanf (Bjarnason 1878: 57).

'Openly sinful men came to Jesus to hear his speech'.

Bersvndgir men como til lafnara varf oc nọ́po peir male hanf oc ọto oc druko með honom (Bjarnason 1878: 57).

'Openly sinful men came to our saviour and they listened to his speech and ate and drank with him'.

Compared to OE bærsynnig, the Old Norse translation of the word does two notable things differently. First, it subsumes publicani and peccatores under a single translation, whereas the Old English gloss renders both words separately. Secondly, it is not used substantively like in both Lindisfarne and Rushworth, requiring the word maðr in order to complete the noun phrase; this is almost certainly due to the different stylistic demands of interlinear glosses when compared to continuous prose, with the former being more restrictive in terms of space and syntactic constraints. It is worth noting, for example, that one instance of bærsynnig as a qualifying adjective does occur in the argumentum to Matthew at the outset of the Lindisfarne text (Skeat 1871-1887: 14), where we find a discussion of Matthew's ceigung to God from bærsynnum wercum ('[Matthew's] calling to God from openly sinful deeds'). ${ }^{25}$ The context of the translation and the early date of the Old Norse text points to bersynðugr being related to OE bærsynnig, perhaps as a loan translation. ${ }^{26}$

24 Note also that Walter interprets the compound as having a sense of 'open' or 'manifest' with his choice of 'offenkundige'. He also points out that publicani is once rendered with the term heiðnir menn 'heathen men' in the Old Icelandic Homily Book in a translation of Matthew 5:46 (see Wisén 1887: 114).

25 Translating cuius [Matthew's] vocatio ad deum ex publicanis actibus suis.

26 Clearly Carr (1939) thought the same despite his reticence on the precise details of any connection. 
We need to be cautious in claiming direct connections between glossing or translation traditions where scripture is concerned, and especially when it comes to individual words. However, I believe there is good reason to see a link between bærsynnig and bersynðugr as reasonably secure for a number of reasons, though whether we can talk only in terms of straightforward loan translation from Old English to Old Norse is another question to which I will return in Section 4.2. First, it is worth highlighting just how rare the word bær is in Old English; the DOE records 24 occurrences of the simplex, two instances of bærlic and three of the adverb bærlice (both in the glosses to Lindisfarne), and seven of bærfōt. ${ }^{27}$ Interestingly, the $D O E$ entry for the last word notes that six of these examples are found "in penitential contexts", which perhaps points to the idea that the word may have had special moralistic associations in certain contexts. ${ }^{28}$ The situation in Old Norse is different, with berr being much more commonly recorded in the ONP as both a simplex and as part of derivative formations. ${ }^{29}$ Of course, this sort of broad comparison can only be instructive rather than categorical, but there is good evidence to suggest that the Old English compound found in the Lindisfarne and Rushworth glosses was the source for ON bersynðugr. In particular, the relative rarity of bær in Old English, paired with other strategies for translating the notion of 'open, public' (especially the much more common openlic and its derivatives), plus the fact that in both languages bærsynnig/bersynðugr is only found in ecclesiastical contexts, ${ }^{30}$ point to a connection between the two.

Pons-Sanz's (2000: 39) work on the Lindisfarne gloss has illustrated how the community of St Cuthbert had close ties with Norse-speakers, and that by the

27 See the figures found in the following entries: $D O E$ s.v. bær; $D O E$ s.v. bærlic; $D O E$ s.v. bærlice; DOE s.v. bær-fōt.

28 Two intriguing instances of the simplex may also point to this: in Genesis B, when Adam and Eve become aware of their nakedness, the narrator recounts that bare gesawon heora lichaman $(1.783 \mathrm{~b}-$ 783a, 'they saw their naked bodies'), and later Adam cries out hwilum of heofnum hate scineð, / blicठ peos beorhte sunne, and wit her baru standað, / unwered wædo (1. 810-812a, 'at times the bright sun shines hot, beams from the heavens, and we two stand here naked, shorn of clothes') (Doane 1991: 228-229). Here bær seems to stand for both 'outer' physical and 'inner' spiritual shame.

29 The ONP provides 218 citations for the simplex (s.v. berr). Adjectival compound formations incorporating the word include: berbakr 'ride bare-back' (ONP s.v. berbakr), berbeinn 'bare-legged' (Cleasby-Vigfússon s.v. bare-legged), berbrynjaðr '?armed only in a coat of mail' (ONP s.v. berbrynjaðr), berdreymr 'who dreams clearly' (ONP s.v. berdreymr), berføtr 'bare-footed, bare-legged' (ONP s.v. berføtr), bermæltr 'plain-spoken' (ONP s.v. bermǽltr) and berskjaldaðr 'without the protection of a shield' (ONP s.v. berskjaldaðr). Nominal compounds include bermæli 'frank mode of expression' (ONP s.v. bermǽli), beryrði 'unambiguous words' (ONP s.v. beryrði) and (possibly, though not generally accepted any more) berserkr 'berserk' (ONP s.v. berserkr).

30 I am grateful to one of the reviewers for pointing out that all sixteen instances of the word cited in the $O N P$ are in ecclesiastical discourse. 
beginning of the tenth century, "there existed a community moving towards ethnic and cultural integration”. Her study of Old Norse loanwords in Aldred's language argues that the words probably had a wide currency in the community - or at least wider than their limited recording in the text indicates (2000: 129; see also her discussion in 2004: 179-180). We might see the coining of the word bærsynnig, then, in the context of a religious community that was acutely aware of the need to engage with Norse speakers on its doorstep who were still in the midst of Christianisation, and communicating new religious narratives and their attendant technical vocabulary would have been of the utmost importance. As Ian J. Kirby (1986: 15) noted in his study of the Old Norse tradition of biblical translation, it was "highly probable that no effective missionary work could take place until the Gospel story was available in the vernacular”. A word like bærsynnig, formed as it is of elements that are easily translatable from Old English to Old Norse, might well be representative of a time when rendering the New Testament for the benefit of speakers from both communities required clear and concise moral explanations rather than detailed accounts of alien cultural concepts: the salient moral point about the publicani was not only that they sinned openly, but also that they could, like the meretrices or gentiles, be redeemed. We thus have a potential missionary context in which the word would have been useful, as public displays of impiety are presumably easier to root out among the newly converted compared to murkier inward rebellion against God. As mentioned above, Matthew is also described as having turned from bærsynnum wercum ('ex actibus publicanis') in the argumentum to the Gospel, and no doubt his example would have provided a particularly good parable for such teaching.

Damian Fleming's (2013: 45) notion of glossing and translation in Old English as a process of "instant exegesis", of transmitting the sense of a word instantly regardless of what the 'true' linguistic meaning might be, is relevant. As he argues (2015: 841) for the Winchester term sundorhalga 'Pharisee', such compounds have practical stylistic use in pedagogical or preaching contexts. This of course would imply that the Lindisfarne and Rushworth glossators and others like them were actively trying to represent language as it was used on a quotidian basis, a proposition that has by no means been endorsed by all scholars who work on glossing traditions, though Kornexl (2003) has argued for the fundamentally natural character of the language of glosses. Given that Jolly (2016: 371) suggests that we should see glossing practice at Chester-le-Street in the tenth century as a collaborative process "intended thereafter for oral use in the community as they engaged in study and reflection of the texts", I think that bærsynnig may well have been a word that was intended for practical preaching as much as it was for contemplative study. The context of the word's formation also has implications for whether we treat ON bersynðugr as a loan translation of the equivalent Old Eng- 
lish compound: there is reason to question whether we are dealing with a loan translation in the traditional sense, and instead we might consider whether the word was being deliberately coined with a bilingual Anglo-Norse community in mind. I will return to this point in Section 4 below.

\subsection{Amulets and Phylacteries: OE healsbōc - ON hálsbók}

\subsubsection{OE healsbōc and its Context}

The next pair of words is OE healsbōc and ON hálsbók, both of which can be translated literally as 'neck-book'. Following the opinions of Taranger (1890: 346) and Fischer (1909: 7), Carr (1939: 35) lists the Old Norse compound as being a loan translation from Old English. In the context of Old English, the word is used exclusively to translate Latin phylacterium 'phylactery; charm, amulet' in the West Saxon version of the Gospels (DMLBS s.v. phylacterium), denoting the small cases - or tefillin - containing parchment excerpts of scripture worn by the pharisees. Thus, with the Old English word, we have another compound with a link to scriptural translation, albeit in a different tradition to both the Lindisfarne and Rushworth glosses.

The exact etymology of the Old English word is not, however, straightforward. While in Old Norse it is very clearly a compound of háls 'neck' and bók, in English the qualifying element presents some problems. The headword $b \bar{o} c$, on the other hand, is unproblematically 'book' and cognate with ON bók. In Old English, the DOE lemma assumes that the qualifying element is heals 'neck', which could alternatively be spelled <hals>, and the various copies of the West Saxon Gospels record both the monophthongal and diphthongal forms (DOE s.vv. heals$b \bar{c} c$; heals). Interestingly, compounds containing heals in the qualifying position in Old English tend to be associated with items that can be worn, including healsbejag 'necklace, collar' (which is unique to Beowulf), healsbeorg 'protection for the neck, hauberk' and healsbeorggold 'gold neck-ring, collar', and so healsbōc could well be modelled along these lines. ${ }^{31}$ Where the first element of healsbōc is spelled $<$ hals>, however, it could also conceivably represent the word hāls 'salvation' (as suggested by Dennis et al. 2012: 82-83 n. 77; see below), though the simplex is recorded only once in Christ $B$ (DOE s.v. hāls), and we cannot discount a connection with the relatively commonplace word hālsung, which could mean (among other things) 'an act of beseeching', 'a swearing or binding under oath' and 'exor-

31 DOE s.vv. heals-bēag; heals-beorg; healsbeorg-gold. 
cism'. ${ }^{32}$ Hālsung appears in a number of compounds itself, including the hapax legomenon hālsungbōc, to which the $D O E$ ascribes the meaning 'book of exorcisms' (s.v. hālsung-bōc), and which a bishop would give to an exorcist upon his ordination (Gneuss 1985: 135). When part of a compound, however, the word is always retained in full and never shortened to hāls $-{ }^{33}$ Alternatively, a connection to $h \ddot{l} l(u)$ 'safety, deliverance, salvation' or hāl 'sound, healthy', is perhaps plausible, but all forms of the qualifying element of healsbōc are consistent in showing stem-final <-s> (DOE s.v. hæ̋lu, hæel 4.a.; DOE s.v. hāl). As we will see, hāls in particular is a feasible (if not definite) alternative to the qualifying word being heals.

In order to figure out which meaning seems more plausible, we need to turn first to the context of the word's use in the Gospels and then to spellings in the various manuscript witnesses for the West Saxon version of the Gospels. The word phylacterium appears in Matthew 23:5, where Christ condemns the vanity of the Pharisees:

Omnia vero opera sua faciunt ut videantur ab hominibus, dilatant enim phylacteria sua et magnificant fimbrias (Kinney 2013: 130).

'Everything they do is done for people to see: They make their phylacteries wide and the tassels on their garments long'.

This is translated in the West Saxon translation as follows:

Ealle heora worc hig doð pæt menn hi geseon; Hig tobrædap hyra healsbæc and mærsiað heora reafa fnadu (Liuzza 1994: 47).

'All their works they do so that men see them; they make their healsbæc large and extend the fringes of their garments'.

Given the context of the passage, with Christ railing against perceived insincere and ostentatious shows of faith, it might be tempting to discount the notion that the first element is intended to be hāls, particularly given the rarity of the word in Old English. Exegetical tradition inevitably complicates matters, however. The word phylacterium has its ultimate root in Greek phylasso, meaning 'to protect', and St Jerome's commentary on Matthew notes that phylacteries were so called

32 More fully: 'an act of beseeching, especially a prayer of supplication', 'adjuration, solemn charge by appeal to something sacred, a swearing or binding under oath' and 'conjuration of demons, exorcism; purification' (DOE s.vv. hālsung, hæelsung, healsung).

33 Other compounds with hālsung include hālsunggebed 'prayer of supplication' (DOE s.v. hālsung-gebed), hālsunggebēn 'prayer of supplication' (DOE s.v. hālsung-gebēn) and hālsungtìma 'time of supplication' (DOE s.v. hālsung-tìma). All of these are hapax legomena. 
because they offer protection and fortification (see Scheck 2008: 260; Hurst and Adriaen 1969: 211). It is certainly possible that the translators were aware of this fact and were attempting to communicate this in their treatment of the word by using hāls 'salvation'. John Chrysostom's homily on Matthew 23:1-3 makes an analogy between the phylacteries worn by the Pharisees and his experience of seeing contemporary women wearing gospel-books around their necks (Schaff 1888: 760). ${ }^{34}$ Theodore de Bruyn's recent study of amulets in the world of late antiquity demonstrates that gospels or parts of gospels were often used as 'physical tokens of power', though he notes that this practice was variously received by the Church Fathers, with John Chrysostom being relatively ambiguous and St Jerome overtly hostile (2017: 25-29). Clearly the idea of books or texts worn in the fashion of amulets had a long tradition (a point to which I will return below), and on the basis of the above evidence, we cannot discount the idea that monophthongal forms of the qualifying word in healsbōc could indeed represent a reflex of hāls, in which case the sense would be something like 'salvation/protection-book' (and thus, by extension, 'amulet').

We must, however, consider the philological evidence from the different versions of the West Saxon Gospels, which survive in six manuscripts and two fragments from the eleventh and twelfth centuries (Liuzza 1988: 42). The eleventhcentury manuscripts known as B and Cp give the forms <healsbec $>$ and $<$ healsbæc > respectively, where <ea> represents the Old English diphthong /æa/, while manuscript $A$ has <halsbæc $>$, with <a $>$ representing the monophthong /a/. The two twelfth-century copies $\mathrm{H}$ and $\mathrm{R}$, on the other hand, both show $<$ halsbec $>{ }^{35}$ Liuzza (1988: 51-52, 63) has shown that both twelfth-century versions derive ultimately from $\mathrm{B}$, though almost certainly with an intermediary exemplar, and at some point in the process of copying the form $<$ healsbec $>$ was altered to $<$ halsbec $>$. Given that /æa/ merged with /æ/ and in turn /a/ in late Old English (Lass 1992: 43-44; Liuzza 1988: 244), it might well be that the scribes of $\mathrm{H}$ and $\mathrm{R}$ were simply updating the spelling of heals to a more familiar early ME hals (OED s.v. halse, hals, $\mathrm{n}^{1}$ ), though $\mathrm{H}$ tended to replace instances of $<$ ea $>$ with $<æ>$ rather than <a> (Liuzza 1988: 96). ${ }^{36}$ As Lass (1992: 44-45) notes, however, the merger of /æa/ with /æ/, and then /æ/ with /a/, led to quite chaotic spelling practices in early Middle English, so we have to be cautious in using spelling as a guide as to what sounds the scribes intended to represent. I suggest that the spelling evi-

34 It is not thought that his works were available in early medieval England (except indirectly) until quite late on, however, and even then, only in snippets which excluded his homilies (see Love 2007; Hall and Norris 2011).

35 For a full description of these, see Liuzza (1988: 42-43).

36 This could be evidence that the change from $<$ ea $>$ to $<a>$ occurred in the lost exemplar. 
dence from $\mathrm{B}$ and $\mathrm{Cp}$, when paired with the changes found in $\mathrm{H}$ and $\mathrm{R}$, points to the idea that the qualifying element in healsbōc was indeed understood to be 'neck' by both the original West Saxon scribes and the later copyists, though the eleventh-century evidence from A (with the spelling <halsbec $>$ ) means this has to be tentative. ${ }^{37}$ It could alternatively be the case that forms with <heals- $>$ and $<$ hals-> point to competing interpretations of phylacterium, with some preferring heals to represent the fact that texts were worn and others hāls to emphasise the possible protective amuletic qualities. And, as spelling became more unstable in the late eleventh and twelfth centuries, it might be that the resultant ambiguity allowed for a degree of semantic wordplay.

\subsubsection{ON hálsbók and its Context}

If we turn to the context of the equivalent Old Norse word in the Icelandic lawcode Grágás, we find different variations of an apparently formulaic phrase used when discussing what is suitable to take an oath upon:

\footnotetext{
Peir scolo taca cros ihönd ser eða boc ba er meire se en háls boc (Finsen 1852: 76).

'They must take a cross in their hand or a book that is more than a hálsbók'.
}

Hann scal taca bóc ihond ser meire enn háls bóc (Finsen 1852: 79).

'He must take a book in his hand [that is] more than a hálsbók'.

Men scolo at boc vina eiða pa alla at u[tar] dómi peirre er heilog orð ero aritin[sic] oc meire en háls bók (Finsen 1852: 80).

'Men must swear all oaths at the outer court on a book in which holy words are written and more than a hálsbók'.

The meaning of ON hálsbók remains ambiguous, but the implication is clearly that it is not suitable for swearing on and a 'proper' book is preferable - meira enn hálsbók -, and certainly we know that swearing on books was absolutely standard practice in medieval Scandinavia, as elsewhere in Europe; indeed, the Old Norse verb bóka 'to attest/affirm with an oath sworn on a book, confirm by oath' is recorded in administrative and legal documents (ONP s.v. bóka). ${ }^{38}$ The text gives no

37 It is also worth noting that we cannot be certain when monophthongisation began to occur.

38 Compare the Old English legal term (ge)bōcian 'to give a grant (of land) by charter' (DOE s.vv. bōcian, bēcan; gebōcian, gebēcan). Note also the fact that OE hālsung has the sense 'a swearing or binding under oath', though of course in the Icelandic context the point is that a hálsbók is not suitable for swearing upon. 
indication as to why a hálsbók should not be suitable, however. Outside Grágás, the word is entirely restricted to a section of Boglunga saga in AM 325 VIII 4 c 4to, where the precise meaning is even less clear than it is in the law texts. The reference comes at the end of an episode in which King Sverrir orders his men to search for a possible pretender by the name of Erlingr. After managing to briefly evade the king's men, he is seized and imprisoned, only to be injured shortly afterwards during a failed escape attempt (we are told gekk hann jafnan haltr síðan 'afterwards he always walked with a limp'). ${ }^{39} \mathrm{He}$ is eventually recaptured, with the saga author bringing the story to a close with the following episode:

Tóku peir hann í Járnberalandi ok drápu hann par, ok hơfou aptr til konungs hálsbók, er hann hafði átt ok nafn hans var á. Ok pá sǫmu hálsbók kenndu margir siðan (Magerøy 1988: 13).

'They caught him in Járnberaland, and killed him there and brought a hálsbók to the king, which he had owned and in which had his name on. And many knew that same hálsbók afterwards'. ${ }^{40}$

From this example it seems as though a hálsbók might refer to an actual book perhaps a gospel-book or personal text of some sort - though the details are so slight that it is impossible to say much more than that.

Most previous commentators and the various Old Norse dictionaries have tended to accept the idea that the compound refers specifically to a book. Páll Vidalin (1854: 219) stated that the word referred to a prayer-book that was worn, while Cleasby-Vigfússon gives the definition 'a book to swear upon', noting that it is usually explained that this is due to the book "being worn around the neck, but no doubt erroneously” and makes a link to OE healsbōc. Johan Fritzner (1867) gave the definition "liden Bog eller deslige som bæres om eller ved halfen" ('a small book or suchlike that is worn around or near the neck'). ${ }^{41}$ More recently,

39 The fact that the hálsbók is brought up in the immediate aftermath of the discussion of Erlingr is potentially significant. If, as discussed below, a hálsbók does have amuletic qualities, then it might make sense that it would be in the possession of one who had undergone a severe physical injury. The Old English metrical charm Wið dweorh indicates that hanging communion wafers with the names of the Seven Sleepers around the neck of the afflicted was part of its remedy, for example. Meaney (1981: 16) has suggested that the word tēah 'a tie, band' (Bosworth-Toller s.v. tēah) in this context might be considered "another Old English equivalent of phylacterium and ligatura".

40 The sixteenth-century Danish version of this section of the text renders hálsbók as Halsbog eller Tegnebog 'neck-book or wallet', giving us an indication of what an earlier reader imagined it to describe (the text is available in parallel to the Old Norse in Magerøy's edition).

41 Cleasby-Vigfússon s.v. háls-bók; Fritzner s.v. halsbók. 
Páll Sigurðsson (1978: 204) suggested that “með ‘bók' er vafalaust átt við Biblíuna (guðspjöllin) eða messusöngsbók" ('the word bók undoubtedly meant the Bible [the gospels] or a service-book'). Taranger (1890: 346), however, stated that it meant "en liden bog, der bæres om halsen som amulet" ('a little book that is worn on the neck like an amulet'), extending the meaning to include 'amulet', probably as a result of his knowledge of the Old English context, and Carr (1939: 35) followed him in this. Andrew Dennis et al. (2012: 82-83 n. 77) have given one of the more extended recent discussions of the compound, reviving the idea that it might have had amuletic properties:

[Hálsbók] might mean 'neck-book' but the etymology is not certain. It is possibly a loan from Old English, which has a word like it, $h(e)$ alsboc, used to translate phylacteria [...] where the first element has been associated with hals 'health, salvation', $h(e)$ alsian 'beseech, adjure, exorcise'. In Icelandic it must have covered small books with invocations used for private devotions or amulets or both. They might sometimes have been worn rather than carried.

That the word might refer to amulets or amuletic texts is an idea worth returning to in light of the above discussion of the word in the Old English context and we must reconsider how likely it is hálsbók refers to a Gospel-book or other 'official' Christian text such as a psalter.

Outside John Chrysostom's observation that women wore gospel-books in late antiquity, the wearing of books around the neck in general was also practiced in parts of early medieval western Europe. The Loch Glashan satchel, for example, seems to date from as early as the sixth or seventh century, and Bernard Meehan (2005: 87) has pointed to the seventh-century text Hisperica famina that describes the making of such a case, while William Fitzherbert, Archbishop of York, is supposed to have worn the Stonyhurst Gospel around his neck "as a special honour" when he visited Durham in the twelfth century to see the tomb of St Cuthbert. Heather Pulliam (2013: 99-101) has also suggested that the tenth-century Book of Deer has images of Mark, Luke and John wearing books as "bearers and keepers of the word", and that the manuscript itself may well have been transported in a satchel. The foot of the Stonegrave great cross in North Yorkshire, which dates from after the Viking settlements, also depicts a figure with what might be a book satchel around their neck (Lang et al. 1991: 42; illustrations 833-836). None of the above goes towards uncovering what, precisely, Scandinavian authors had in mind when they used the term hálsbók, but we do at least have some evidence for the wearing of books in early medieval north-west Europe, even if this was perhaps (as in the case of the Stoneyhurst Gospel) only in ritual contexts.

However, we know that it was routine to swear oaths on Christian objects such as crucifixes, relics or gospel-books in medieval Scandinavia, with these items replacing earlier preferences for rings, stones and swords (Stein-Wilkeshuis 
2002: 156-157). ${ }^{42}$ It is unclear why Grágás would therefore forbid swearing on a hálsbók if it were a gospel-book or prayer-book as previous commentators have suggested. It is important to take seriously the idea that the word may well have encompassed amuletic objects, whether whole books, short snippets of text or non-textual items. MacLeod and Mees (2006: 184-185) note that early medieval Christian amulets

[...] typically record short benedictions or prayers, or snatches of biblical or liturgical tracts. Often written on parchment, they were sometimes carried in small cases and were worn about the body.

The parallel with the practice of the Pharisees is obvious, and MacLeod and Mees go on to note that such amulets, while most often written in Latin, could also encompass vernacular languages, and might be in Roman or runic script (see esp. 2006: 184-210). In the context of Viking Age England, John Hines (2017) has studied the possible amuletic qualities of the runic inscription on the eleventh-century Saltfleet spindle whorl, which invokes Óðinn and Heimdallr for aid, but this pagan example is a relative rarity. More pertinent to the current discussion is his forthcoming study of a series of tenth- or eleventh-century lead sheets from the east of England inscribed with various Christian runic formulae (and one piece of gibberish) that each seem to have amuletic properties, with text encompassing "intercessory prayers, fragments of litany, and even magical rituals" (Hines 2019: 53). ${ }^{43}$ The tradition of textual runic amulets also continued unabated in later medieval Scandinavia in a variety of different forms, with most being "overtly Christian" and some being inscribed on lead (MacLeod and Mees 2006: 188190). Clearly there were a multiplicity of literate traditions outside of learned manuscript culture in England and Scandinavia, and it might well have become necessary to circumscribe what did or did not count as a 'legitimate' object for taking an oath upon during the Christianisation process, with even amuletic Christian texts occupying a rather uncomfortable position between the superstitious and the religious. I think there is good reason to construe the headword of

42 Stein-Wilkeshuis also notes that, in an eastern context, the Rus were introduced to the Byzantine tradition of swearing on 'oath-books' (2002: 157). The Swedish Forsaring contains an extensive runic inscription that has been interpreted specifically as an object that might have been used in an oath-taking ceremony (Stein-Wilkeshuis 2002: 64), though the dating is rather hotly debated (Brink 1996).

43 I am grateful to the editors of Anglia for providing me with a proof of this chapter. Hines (2019: 53) also notes that the one runic amulet that is "gobbledygook" (the Saint Benet's plaque) is written in the Scandinavian Younger Futhark, something that he argues is an "informed choice". 
hálsbók more broadly as 'text' rather than referring only to a book in the modern sense of the word. ${ }^{44}$

So, is there a link between the Old English and the Old Norse terms as previous scholars have suggested? There are a few more scraps of evidence that we should consider with regards to the Old English term in particular that I argue allow for the likelihood of a relationship, especially in the context of Christianisation and the sort of topological analogising between past and present I noted that underpinned the formation of bærsynnig/bersynðugr. First, it is worth considering the Latin term phylacterium in Anglo-Latin texts that refer to explicitly pagan rather than just Jewish - practice, with Bede narrating that many of the peoples St Cuthbert sought to convert often abandoned their faith and looked to the 'false remedies' of idolatory, quasi plagam per incantationes, vel fylacteria, vel alia quaelibet daemonicae artis arcana cohibere valerent (Colgrave and Mynors 1969: 432433; 'as though they might deflect a blow from God the creator through spells or amulets or any other secrets of demonic craft'). ${ }^{45}$ The Old English translation of this part of the Historia Ecclesiastica renders this instance of the word as lyfesn 'a charm, an amulet' (Miller 1890: 362; Bosworth-Toller s.v. lybesn), which is elsewhere used to translate Latin strena 'a lucky token or gift' (DMLBS s.v.; see also the discussion in Wright 2016: 172). ${ }^{46}$ If we turn to the Lindisfarne and Rushworth glosses, we find phylacterium in Matthew 25:3 rendered with the hapax legomenon pweng, ${ }^{47}$ to which Bosworth-Toller ascribes the meaning 'a band' (s.v. pweng) and cross-references with the more expected Old English form pwang (> Modern English thong). ${ }^{48}$ Given the context, it seems likely that the glossators understood a pweng to be something that could be worn, and the OED entry for thong gives 'phylactery' as an obsolete sense, quoting both the Lindisfarne and Rushworth glosses (s.v. thong, n.). ${ }^{49}$ It is likely that the word is used metonymically to repre-

44 I am grateful to Heather O'Donoghue for pointing out to me the rather obvious fact that the text we call Îslendingabók is not, in fact, much of a book at all (a reviewer notes that we can also, of course, include Landnámabók). Quite apart from the example of hálsbók, it would be worth revisiting our standard definitions of the Old English and Old Norse reflexes of PGmc ${ }^{*} b \bar{o} k s$ so that they incorporate the sense 'text'.

45 This statement has parallels in St Augustine of Hippo's De doctrina Christiana.

46 Lyfesn is also used to gloss phylacterium in the Cleopatra Glossary.

47 With the spellings <ðuencgu > in Lindisfarne and <pwænge > in Rushworth (see OED s.v. thong, b.).

48 This word is cognate with ON pvengr 'rem, lædersnor' ('strap, leather thong', ONP s.v.). Elsewhere in the Lindisfarne gloss, OE pwang (spelt <ðuong>) is used to refer to Latin corrigia 'lace, thong' (DMLBS s.v.). See also the brief discussion in Ross (1979: 197).

49 Note that this entry has not yet been updated. It is probably on the basis of the $O E D$ that MacLeod and Mees (2006: 4) ascribe the meaning 'amulet' to pweng. 
sent the amulet and the band to which it is attached, though there is no clear indication that this needed to be textual. Looking to the continent, Old High German records the term zoupargiscrîp, meaning quite literally 'magical writing' (MacLeod and Mees 2006: 4). When we consider the term healsbōc within this constellation of Old English and other vernacular translation traditions, it is likely that it was intended to not just communicate something about the Pharisees' own habit of wearing snippets of scripture, but also to draw analogies with contemporary amuletic practices, Christian or otherwise, that would have resonated in late Viking Age England.

The second piece of evidence to take into account is the exegesis surrounding the term phylacterium. In his commentary on chapter 23 of the Gospel of Matthew, St Jerome is damning of the wearing of phylacteries in general, claiming that the same practice of wearing religious texts occurred among the contemporary Babylonians and other eastern peoples of his day, and that by this custom religiosus in populis iudicatur (Hurst and Adriaen 1969: 211; 'they are judged religious among their people'). His anxiety about phylacteria is rooted in the idea that the Pharisees did not understand that the scripture should be carried in the heart rather than on the body and that the contemporary fashion for women to wear small gospel-books and fragments of the cross shows that habent quidem zelum Dei sed non iuxta scientiam (Hurst and Adriaen 1969: 212; 'they have zeal for God, certainly, but not in accordance with knowledge'). The Gospel of Matthew continues this theme in 23:17, condemning those who swear oaths bound by the gold of the temple, but not by the temple itself, asking: quid enim maius est? Aurum, an templum, quod sanctificat aurum? (Kinney 2013: 132; 'for what is greater? The gold, or the temple that sanctifies the gold?'). The problem, as St Jerome explains, is that the Pharisees held the wealth and physical aspects of religion in higher regard than they held its spiritual truth (Hurst and Adriaen 1969: 215). This condemnation was repeated throughout the early medieval period, perhaps most significantly for the present discussion in Alcuin's writings; Charles D. Wright notes that he condemns the wearing of scripture around the neck in his letter to Æthelhard, archbishop of Canterbury, for example, arguing that priests should carry gospelteachings in their minds (2016: 187-188). ${ }^{50}$ With the coining of healsbōc, the translators of the West Saxon versions of the Gospels were tapping into a long-standing condemnatory discourse on the appropriate use of religious text, and possibly also making a direct reference to contemporary amuletic use of scripture like the

50 See also Blair (2005: 170-175) for a discussion on the tolerance of amulets by Christian authorities in general, though with a somewhat hazy distinction between 'charms' and 'amulets'. The primary study on early medieval amulets from England in the archaeological record remains Meaney (1981), especially the discussion on the Christian background (at 8-15). 
inscribed lead sheets mentioned above. Jonathan Davis-Secord (2016: 42-43) notes that compound words tend to always be understood as compounds despite some degree of lexicalisation, with each constituent word being processed individually, and the formation healsbōc extended the Old English tradition of translations of phylacterium by making its textual nature explicit while simultaneously maintaining the image of something that is worn externally.

Roy Liuzza (1998: 5-7) has argued that, despite the translation being "workaday, practical, like nothing special”, the West Saxon versions of the Gospels were likely intended for everything from private devotional use ("lay or clerical") to pedagogical instruction. In her study of manuscripts A and F of the Gospels, Ursula Lenker (1999: 173-174) discounts the idea that the texts were used in the liturgy, but argues that there is every possibility that vernacular readings were carried out during mass, and certainly the number of copies that survive point to some degree of demand for access to scripture in the vernacular. Given all this, it is evident that a word like healsbōc might have been easily transferred to newly arrived (and in many cases newly converted) Norse speakers in the south-west of England and beyond in the aftermath of Knútr the Great's accession in 1016, where a pedagogical distinction between amuletic texts and 'official' texts perhaps became necessary. Indeed, from the tenth and eleventh centuries onwards there was a growing general anxiety about the desire to control 'good' and 'bad' literacy, with R. I. Moore (1994: 22) noting a "nervousness of the magical properties associated with books and their use" across western Europe, a worry that underpinned later conceptions of heresy (though reflecting older concerns over the use and abuse of writing). And of course, at the outset of the eleventh century, Ælfric of Eynsham was voicing his own anxiety over the power of the translated written word to mislead the unlearned, something that would have gained an extra degree of urgency in the aftermath of new Viking attacks and settlements (even in spite of the nominal Christianity of many of these men). ${ }^{51}$ It is important to bear in mind the need for texts in the Danelaw and across vast swathes of Scandinavia, which would have been acute from the moment of conversion; suddenly there was a real need for gospel-books, psalters and the like in churches and minsters, no doubt many of them glossed. As Kirby (1986: 10) has argued, the missionaries would have

51 We can only imagine that the fact that non-Christian or recently converted Scandinavians had access to a form of writing that could be etched onto precious personal objects caused some degree of anxiety among the clergy. Indeed, the existence of runic literacy in earlier periods may well have caused similar anxiety; as Hines (2011: 295) notes of the eighth century, "[t]here was a literate community in which two scripts, as well as two languages, were in extensive use”. 
included men who would presumably have been accustomed to the idea of having at least parts of the Bible available in the vernacular, and may consequently be supposed to have at least encouraged a similar development in the lands in which they preached the gospel. ${ }^{52}$

Suddenly a context emerges in which 'official' texts become freed from institutional control and the potential for misuse of written texts - even by professed Christians - must have been ever-present, both in long Christianised places and on the evangelising fringes of northern Europe. In Grágás, then, we might detect a reflection of this earlier tension, where the law-code deliberately sets suitable Christian items to swear upon - crucifixes and books containing heilog orð 'holy words' - against rather more superstitious objects or popular devotional texts, hálsbækr 'phylacteries, amulets', but with the word's original analogical connection to the pharisees' phylacteries and insincere displays of faith perhaps long forgotten.

\section{Communicating the Gospel in Viking Age England}

\subsection{Loan Translation as Cultural Translation}

As I stated at the outset of Section 3, we should of course be wary of drawing connections between words where none exists, and I make no claim to have provided categorical evidence of a relationship between our two sets of compounds. On the basis of the foregoing argument, however, I believe there is good reason to suppose that the Old Norse words are loan translations from Old English (though the overall picture might be slightly more complex than this, see below, Section 4.2). The common thread running through my argument for both words has been, to quote Stanton (2002: 9), that the interrelated processes of glossing and translation

engage with a body of authoritative works (taken individually and together as a tradition) and animate them in a cultural milieu different from that in which they were originally written.

52 On the improbability of missionaries embarking on their endeavours without access to Christian textual culture, see also Abrams (1995) and Corrêa (2008). 
It is simply not enough for translators to follow exegetical and patristic scholarship mechanically in their own vernacular renderings; they have to in some way be rooted in the context of their own times for them to be meaningful to them and their contemporaries. For both bærsynnig/bersynðugr and healsbōc/hálsbók, the glossators and translators seemed to have been working on the assumption that unfamiliar cultural terms must be clearly communicable; as Lesley Abrams (2013: 22-23) has demonstrated, the process of 'cultural translation' - which of course incorporates the linguistic and the non-linguistic - is central to conversion efforts, usually by finding common ground between Christianity and existing beliefs. Davis-Secord (2016: 39) has argued that one of the key aspects of vernacular compounds as "translation tools" in early medieval England was precisely their ability to render far-distant cultural contexts in situations that are more familiar (or as he terms it, "acceptable") to a contemporary audience. Together, I think that the pair of words I have examined show how the careful coining of interpretative compounds along the lines suggested by Davis-Secord and Fleming could be pedagogically useful not only in the context of a classroom or church service, but also in a missionary field where clear and precise explanations of technical biblical terminology would have been vital.

In the context of tenth- and eleventh-century England (if not necessarily contemporaneous Scandinavia), both words tap into the general anxiety over what we might call 'openly sinful' practices. We can see the compounds in the context of the outward policing of appearance and behaviour that figures like Alcuin engaged in at the outset of the Viking Age, and Ælfric and Wulfstan at its twilight, as well as the general denunciations of heathen practices that are found in later Anglo-Saxon law-codes. Wulfstan, in decrying the woruldsceamu 'worldly or public shame' of his fellow countrymen (Bethurum 1957: 272), listed in detail the public displays of sinfulness that people are alleged to have been engaging in, from prostitution and sorcery to oath-breaking and thievery, lamenting that the teachings of scripture were being resolutely ignored. In his letter to brother Eadweard, Ælfric attacked the adoption of the outward fashions of hæðenra manna 'heathen men' and the abandonment of proper Englisc (and consequently Christian) custom (Clayton 2002: 280-281). Both men were writing within an established discourse that had its roots in Alcuin's eighth-century letter to King Æthelred of Northumbria, where various sinful practices and vain fashions were condemned (Clayton 2002: 269-270). While the reality of these individual censured practices in Viking Age England can be debated, it is clear that significant numbers of nonChristian incomers caused plenty of consternation for the church. Gospel stories about openly sinful publicans and the false vanity of the Pharisees would consequently have had a special resonance for churchmen seeking to do away with morally suspect or otherwise un-Christian customs. 


\subsection{The Speech Community of the Late Anglo-Saxon Church}

I want to finish this part with some speculative remarks with regards to the speech communities from which these compounds emerged, and particularly whether we should necessarily see them as being loan translations from Old English to Old Norse in the strictest sense of the term. The fact that the words in both languages are made up of cognate elements, plus their emergence in a tenth-century context (albeit from different regions), raises questions about the linguistic make-up of textual communities in early medieval England and whether ease of translation between different Germanic languages was something that was actively considered in translation practice. As mentioned above, Pons-Sanz (2000: 39) has argued that the community of St Cuthbert was moving towards "ethnic and cultural" integration with Norse speaking incomers, a process that it probably had to come to terms with sooner than the West Saxon church, though the latter was also accommodating men of Scandinavian descent to quite high positions by the midtenth century, namely archbishops Oda and Osketel (Abrams 1995: 215). It is possible that words like bærsynnig and healsbōc were being coined in the knowledge that they should be understandable to people who were used to code-switching between Old English and Old Norse.

While Abram (2004: 22) has pointed to the possibility of bilingual AngloNorse textual communities in twelfth-century Worcester, we need to bear in mind that the Anglo-Saxon church was a characteristically polyglot institution throughout its history, and particularly in the aftermath of Knutr the Great's accession in the early eleventh century (O'Donnell et al. 2013). It is inconceivable that in such an environment discussion over the process of translation and the similarities between vernacular languages did not take place, though we are largely left to infer such information. Matthew Townend's (2002) study of place-names in Viking Age England and analogical correspondences between cognate Old EnglishOld Norse terms is one of the great recent examples of this, and he has more recently developed his original idea of cognate substitution to suggest that the renaming of certain Danelaw settlements may have involved English and Norse speakers "using a mutually transparent term of reference" (2013: 119) - that is, by selecting mutually intelligible cognate terms. There is another scrap of parallel evidence that I also think is instructive when thinking about the linguistic makeup of the English church (and royal court) at this time. The eleventh-century Encomium Emmae Reginae, which was written for Knútr the Great's wife Emma by a monk based at the abbey of Saint Bertin in Flanders, breaks from the main thrust of his narrative to go on a brief digression on the etymology of the name of the royal couple’s son, Harðaknútr: 
Uocator siquidem Hardocnuto, nomen patris referens cum additamento, cuius si ethimologia Theutonice perquiratur, profecto quis quantusue fuerit dinoscitur.' 'Harde' quidem 'uelox' uel 'fortis', quod utrumque, multoque maius his, in eo uno cognosci potuit (Campbell 1998: 34).

'Indeed he would be named Harðaknútr, recalling the name of his father with an addition. If the etymology is explored in Germanic, his greatness will be truly discerned. "Harde", indeed, [means] "swift" or "strong", either of which, and many more characteristics as well, one could perceive in him alone'.

The author was most likely not a native speaker of either Old English or Old Norse, but as a Fleming he was probably a speaker of a Germanic language; so it is significant that he reflects on an Old Norse personal name in terms of its constituent elements being Theutonica, 'Germanic'. Given that the Encomiast was writing on behalf of an Old English speaking patron and her native Old Norse speaking husband, and by extension for a court characterised by its multilingualism, it is likely that he understood the term would be comprehensible to a wide range of vernacular Germanic speakers. And if a native of Flanders was routinely thinking crosslinguistically about different vernaculars, then it is certain that this was commonplace among the educated elite of the English (or indeed Anglo-Scandinavian) church and court. I end this section with the conjecture that compounds like bærsynnig and healsbōc might represent this sort of bilingual thinking, whereby a word is deliberately coined in the knowledge that it would have to be accessible to - or easily translatable between - more than one speech community, particularly if it might have some practical (and in this case) pedagogical value. That signs of mutual intelligibility might not be confined entirely to place-names offers a clear way to reconsider much of our vernacular evidence afresh.

\section{Conclusion}

This study has provided a small insight into the linguistic relations between English and Norse speakers in the Viking Age and beyond, and the implications are manifold. There are still plenty of lexical borrowings between Old English and Old Norse, that warrant careful reassessment, and this is especially true of a number of compounds from the tenth and eleventh centuries that have proven resistant to secure identification in either direction and that are scattered across prose, poetry and place-name evidence. By re-approaching these words with the firm view that early medieval England was a multilingual society, and often had Norse and other Germanic speakers in positions of relative power, we might be better placed to draw a more cogent picture of how and why certain compounds were formed in 
the period. In terms of the development of early Old Norse literary vocabulary in the twelfth century, there is more scope for broader cross-linguistic comparison with Old English and other Germanic languages, especially where translation practice is concerned. It need not be confined to straightforward cognate formations either, and we should perhaps give more thought to commonalities between vernacular translation practices in general. While it might be the case that the borrower cannot often be distinguished from the lender, the real picture might be altogether more compelling. ${ }^{53}$

\section{Works Cited}

Abram, Christopher. 2004. "Anglo-Saxon Influence in the Old Norwegian Homily Book”. Mediaeval Scandinavia 14: 1-35.

Abram, Christopher. 2007. “Anglo-Saxon Homilies in their Scandinavian Context”. In: Aaron J. Kleist (ed.). The Old English Homily: Precedent, Practice and Appropriation. Turnhout: Brepols. 425-444.

Abrams, Lesley. 1995. "The Anglo-Saxons and the Christianization of Scandinavia". Anglo-Saxon England 24: 213-249.

Abrams, Lesley. 2000. "Conversion and Assimilation." In: Dawn M. Hadley and Julian D. Richards (eds.). Cultures in Contact: Scandinavian Settlement in England in the Ninth and Tenth Centuries. Turnhout: Brepols. 135-153.

Abrams, Lesley. 2013. "Bede, Gregory, and Strategies of Conversion in Anglo-Saxon England and the Spanish New World". Jarrow Lecture: 1-41.

Bethurum, Dorothy (ed.). 1957. The Homilies of Wulfstan. Oxford: Clarendon.

Bjarnarson, Porvaldur (ed.). 1878. Leifar fornra kristinna frœða íslenzkra: Codex Arna-Magnæanus 6774 to auk annara enna elztu brota af ízlenzkum guðfrœðisritum. Copenhagen:

H. Hagerup.

Blair, John. 2005. The Church in Anglo-Saxon Society. Oxford: Oxford University Press.

Bosworth-Toller = An Anglo-Saxon Dictionary. 1898. Eds. Joseph Bosworth and Thomas Northcote Toller. Supplement. 1921. Oxford: Oxford University Press. <http://www.bosworthtol ler.com/> [last accessed 26 August 2019].

Brink, Stefan. 1996. "Forsaringen - Nordens äldsta lagbud”. In: Else Rosedahl and Preben Meulengracht Sørensen (eds.). Beretning fra femtende tværfaglige vikingesymposium. Højbjerg: Hikuin. 27-55.

Buse, J. E. 1955. "Old and Middle English Loan Words in Old West Norse”. Unpubl. PhD thesis, University of Cambridge.

53 I would like to thank Matthew Townend for his comments on an early draft of this article. I am also grateful to various colleagues for the many helpful comments I received when I delivered embryonic versions of this article in talks at University College London, the University of York and the University of Oxford. The genesis of this research was made possible by the generous funding of the Wolfson Foundation. 
Campbell, Alistair (ed.). 1998. Encomium Emmae Reginae. Cambridge: Cambridge University Press.

Carr, Charles T. 1939. Nominal Compounds in Germanic. London: Oxford University Press.

Clayton, Mary. 2002. "An Edition of Ælfric's Letter to Brother Edward”. In: Elaine Treharne and

Susan Rosser (eds.). Early Medieval English Texts and Interpretations: Studies Presented to Donald G. Scragg. Tempe, AZ: Arizona Centre for Medieval and Renaissance Studies.

261-283.

Cleasby-Vigfússon = An Icelandic-English Dictionary. 1874. Eds. Richard Cleasby and Guðbrandur Vigfússon. Oxford: Clarendon. <https://www.ling.upenn.edu/ kurisuto/germanic/oi_ cleasbyvigfusson_about.html> [last accessed 26 August 2019].

Colgrave, Bertram and R.A.B. Mynors (eds.). 1969. Bede's Ecclesiastical History of the English People. Oxford: Oxford University Press.

Corrêa, Alicia. 2008. "A Mass for St Birinus in an Anglo-Saxon Missal from the Scandinavian Mission-Field". In: Julia Barrow and Andrew Warham (eds.). Myth, Rulership, Church and Charters: Essays in Honour of Nicholas Brooks. Aldershot: Ashgate. 167-188.

Dance, Richard. 2003. Words Derived from Old Norse in Early Middle English: Studies in the Vocabulary of the South-West Midlands Texts. Tempe, AZ: Arizona Center for Medieval and Renaissance Studies.

Dance, Richard. 2004. "North Sea Currents: Old English-Old Norse Relations, Literary and Linguistic”. Literature Compass 1: 1-10.

Dance, Richard. 2019. "Words Derived from Old Norse in Sir Gawain and the Green Knight: An Etymological Survey". Transactions of the Philological Society 116: 1-600.

Davis-Secord, Jonathan. 2016. Joinings: Compound Words in Old English Literature. Toronto: University of Toronto Press.

de Bruyn, Theodore. 2017. Making Amulets Christian: Artefacts, Scribes, and Contexts. Oxford: Oxford University Press.

de Vries, Jan (ed.) = Altnordisches Etymologisches Wörterbuch. 1977. 2nd ed. Leiden: Brill.

Dennis, Andrew, Peter Foote and Richard Perkins (trans.). 2012. Laws of Early Iceland: Grágás I. Winnipeg: University of Manitoba Press.

DMLBS = The Dictionary of Medieval Latin from British Sources. 2013. Eds. Ronald E. Latham, David Howlett and Richard Ashdowne. Oxford: Oxford University Press. <https://logeion. uchicago.edu/lexidium> [last accessed 26 August 2019].

Doane, Alger N. (ed.). 1991. The Saxon Genesis: An Edition of the West Saxon Genesis B and the Old Saxon Vatican Genesis. Madison, WI: The University of Wisconsin Press.

$D O E=$ Dictionary of Old English in Electronic Form: $A$ to I. 2018. Eds. Antonette diPaolo Healey et al. Toronto: University of Toronto. <http://www.doe.utoronto.ca> [last accessed 26 August 2019].

DOEC = Dictionary of Old English Corpus. 2007. Eds. Antonette diPaolo Healey et al. Toronto: University of Toronto. <http://www.doe.utoronto.ca/pages/pub/web-corpus.html> [last accessed 26 August 2019].

Falk, Hjalmar and Alf Torp (eds.). 1910. Norwegisch-dänisches etymologisches Wörterbuch. Heidelberg: Winter.

Finsen, Vilhjálmur (ed.). 1852. Grágás: Elzta lögbók íslendinga. Copenhagen: Fornritafjelags Norðurlanda.

Fischer, Frank. 1909. Die Lehnwörter des Altwestnordischen. Berlin: Mayer \& Müller.

Fleming, Damian. 2013. "Jesus, that is hæland: Hebrew Names and the Vernacular Savior in Anglo-Saxon England”. Journal of English and Germanic Philology 112: 26-47. 
Fleming, Damian. 2015. “Sundorhalgan, Winchester, and ÆElfric”. Review of English Studies 66: 822-842.

Frank, Roberta. 2007. "Terminally Hip and Incredibly Cool: Carol, Vikings, and Anglo-Scandinavian England". Representations 100: 23-33.

Frankis, John. 2016. From Old English to Old Norse: A Study of Old English Texts Translated into Old Norse with an Edition of the English and Norse Versions of Alfric's De falsis diis. Oxford: The Society for the Study of Medieval Languages and Literature.

Gade, Kari E. 2007. “Flfric in Iceland”. In: Judy Quinn, Kate Heslop and Tarrin Wills (eds.). Learning and Understanding in the Old Norse World: Essays in Honour of Margaret Clunies Ross. Turnhout: Brepols. 321-339.

Gammeltoft, Peder and Jakob P. Holck. 2007. “Gemstēn and other Old English Parallels: A Survey of Early Old English Loanwords in Scandinavian”. NOWELE: North-West European Language Evolution 50-51: 131-161.

Gneuss, Helmut. 1985. "Liturgical Books in Anglo-Saxon England and their Old English Terminology”. In: Michael Lapidge and Helmut Gneuss (eds.). Learning and Literature in AngloSaxon England. Cambridge: Cambridge University Press. 91-141.

Gunn, Nikolas. 2017. “Contact and Christianisation: Reassessing Purported English Loanwords in Old Norse". Unpubl. PhD thesis, University of York.

Hall, Thomas N. 2000. “Old Norse-Icelandic Sermons”. In: Beverly M. Kienzle (ed.). The Sermon. Turnhout: Brepols. 661-705.

Hall, Thomas N. and Michael Norris. 2011. "The Chrysostom Texts in Bodley 516". The Journal of Theological Studies 62: 161-175.

Haspelmath, Martin. 2009. "Lexical Borrowing: Concepts and Issues." In: Martin Haspelmath and Uri Tadmor (eds.). Loanwords in the World's Languages. Berlin: de Gruyter. 35-54.

Haugen, Einar. 1950. "The Analysis of Linguistic Borrowing.” Language 26: 210-231.

Hines, John. 2011. "New Light on Literacy in Eighth-Century East Anglia: A Runic Inscription from Baconsthorpe, Norfolk.” Anglia 129: 281-296.

Hines, John. 2017. “A Glimpse of the Heathen Norse in Lincolnshire”. In: Eric Cambridge and Jane Hawkes (eds.). Crossing Boundaries: Interdisciplinary Approaches to the Art, Material Culture, Language and Literature of the Early Medieval World. Oxford: Oxbow. 118-126.

Hines, John. 2019 [forthcoming]. "Practical Runic Literacy in the Late Anglo-Saxon Period: Inscriptions on Lead Sheet”. In: Ursula Lenker and Lucia Kornexl (eds.). Anglo-Saxon MicroTexts. Berlin: de Gruyter. 30-59.

Höfler, Otto. 1931. “Altnordische Lehnwortstudien I”. Arkiv för Nordisk Filologi 47: 248-297.

Höfler, Otto. 1932. “Altnordische Lehnwortstudien II \& III”. Arkiv för Nordisk Filologi 48: 1-30 and 213-241.

Hofmann, Dietrich. 1955. Nordisch-englische Lehnbeziehungen der Wikingerzeit. Copenhagen: Munksgaard.

Hurst, David and Marcus Adriaen (eds.). 1969. S. Hieronymi Presbyteri Opera. Commentariorvm in Mathevm libri iv. Corpus Christianorum Series Latina XX. Turnhout: Brepols.

Jolly, Karen. 2016. "The Process of Glossing and Glossing as Process: Scholarship and Education in Durham, Cathedral Library, MS A.iv.19”. In: Julia Fernández Cuesta and Sara M. PonsSanz (eds.). The Old English Gloss to the Lindisfarne Gospels: Language, Author and Context. Berlin: De Gruyter. 327-336.

Kastovsky, Dieter. 1992. "Semantics and Vocabulary". In: Richard M. Hogg (ed.). The Cambridge History of the English Language. Volume I: The Beginnings to 1066. Cambridge: Cambridge University Press. 290-408. 
Kinney, Angela M. (ed.). 2013. The Vulgate Bible. Volume VI: The New Testament. Cambridge, MA: Harvard University Press.

Kirby, Ian J. 1986. Bible Translation in Old Norse. Geneva: Droz.

Kornexl, Lucia. 2003. “'Unnatural Words?' Loan-formations in Old English Glosses”. In: Dieter Kastovsky and Arthur Mettinger (eds.). Language Contact in the History of English. Frankfurt am Main: Lang. 195-216.

Lang, James, John Higgitt, Raymond I. Page and John R. Senior. 1991. Corpus of Anglo-Saxon Stone Sculpture. Volume 3: York and Eastern Yorkshire. Oxford: Oxford University Press.

Lass, Roger. 1992. “Phonology and Morphology”. In: Norman Blake (ed.). The Cambridge History of the English Language. Volume 2: 1066-1476. Cambridge: Cambridge University Press.

Lendinara, Patrizia. 2016. “The 'Unglossed' Words of the Lindisfarne Glosses”. In: Julia Fernández Cuesta and Sara M. Pons-Sanz (eds.). The Old English Gloss to the Lindisfarne Gospels: Language, Author and Context. Berlin: De Gruyter.

Lenker, Ursula. 1999. "The West Saxon Gospels and the Gospel-Lectionary in Anglo-Saxon England: Manuscript Evidence and Liturgical Practice”. Anglo-Saxon England 28: 141-178.

Lindsay, Wallace M. 1911. Isidori Hispalensis Episcopi Etymologiarvm sive originvm, Tomus I, Libros I-X. Oxford: Clarendon.

Liuzza, Roy M. 1988. "New Wine in Old Bottles: The Twelfth-Century Texts of the West-Saxon Gospels”. Unpubl. PhD thesis, Yale University.

Liuzza, Roy M. (ed.). 1994. The Old English Version of the Gospels. Volume I: Text and Introduction. EETS OS 301. Oxford: Oxford University Press.

Liuzza, Roy M. 1998. “Who Read the Gospels in Old English?”. In: Peter S. Baker and Nicholas Howe (eds.). Studies in Medieval English Language and Literature in Honour of Fred C. Robinson. Toronto: University of Toronto Press. 3-24.

Liuzza, Roy M. (ed.). 2000. The Old English Version of the Gospels. Volume II: Notes and Glossary. EETS OS 314. Oxford: Oxford University Press.

Love, Rosalind. 2007. "Bede and John Chrysostom”. Journal of Medieval Latin 17: 72-86.

Lutz, Angelika. 2013. "Language Contact and Prestige”. Anglia 131: 562-590.

Lutz, Angelika. 2017. "Norse Loans in Middle English and their Influence on Late Medieval London English”. Anglia 135: 317-357.

MacLeod, Mindy and Bernard Mees. 2006. Runic Amulets and Magic Objects. Woodbridge: Boydell.

Magerøy, Hallvard (ed.). 1988. Soga om Birkebeinar og Baglar: Boglunga Sogur, Del II. Oslo: Solum.

Magnússon, Ásgeir Blöndal. 1989. Íslensk orðsifjabók. Reykjavík: Háskóli Íslands.

McKinnell, John. 1990-1993. "The Context of Volundarkviða”. Saga-Book 23: 1-27.

McKinnell, John. 2001. “Eddic Poetry in Anglo-Scandinavian Northern England”. In: James Graham-Campbell, Richard Hall, Judith Jesch and David N. Parsons (eds.). Vikings and the Danelaw: Select Papers form the Proceedings of the Thirteenth Viking Congress, Nottingham and York, 21-30 August 1997. Oxford: Oxbow Books. 327-342.

Meaney, Audrey L. 1981. Anglo-Saxon Amulets and Curing Stones. Oxford: BAR.

Meehan, Bernard. 2005. "Book Satchels in Medieval Scotland and Ireland". In: Anne Crone and Ewan Campbell (eds.). A Crannog of the First Millennium AD: Excavations by Jack Scott at Loch Glashan, Argyll, 1960. Edinburgh: Society of Antiquaries of Scotland. 85-92. 
Miller, Thomas (ed.). 1890. The Old English Version of Bede's Ecclesiastical History of the English People. EETS OS 96. Oxford: Horace Hart.

Moore, Robert I. 1994. "Literacy and the Making of Heresy". In: Peter Biller and Anne Hudson (eds.). Heresy and Literacy, 1000-1530. Cambridge: Cambridge University Press. 19-37.

O’Donnell, Thomas, Matthew Townend and Elizabeth M. Tyler. 2013. “European Literature and Eleventh-Century England”. In: Clare A. Lees (ed.). The Cambridge History of Early Medieval English Literature. Cambridge: Cambridge University Press. 607-636.

OED = The Oxford English Dictionary. 3rd ed. March 2000-. Eds. John A. Simpson and Michael Proffitt. <https://www.oed.com> [last accessed 26 August 2019].

ONP $=$ Ordbog over det norrøne prosasprog. 2019. Eds. Aldís Sigurðardóttir, Alex Speed Kjeldsen, Bent Chr. Jacobsen et al. Copenhagen: The Arnamagnæan Collection. <https:// onp.ku.dk/onp/onp.php> [last accessed 26 August 2019].

Fritzner, Johan. 1867. Ordbog over det gamle norske sprog. Oslo: Feilberg \& Landmark. <http:// www.edd.uio.no/perl/search/search.cgi?appid=86\&tabid=1275> [last accessed 26 August 2019].

Pons-Sanz, Sara M. 2000. Analysis of the Scandinavian Loanwords in the Aldredian Glosses to the Lindisfarne Gospels. Valencia: Lengua Inglesa, Universidad de València.

Pons-Sanz, Sara M. 2004. "A Sociolinguistic Approach to the Norse-Derived Words in the Glosses to the Lindisfarne and Rushworth Gospels". In: Christian Kay, Carole Hough and Irené Wotherspoon (eds.). New Perspectives on English Historical Linguistics: Selected Papers from 12 ICEHL, Glasgow, 21-26 August 2002. Volume II: Lexis and Transmission. Amsterdam: Benjamins. 177-192.

Pons-Sanz, Sara M. 2007. "Two Compounds in the Old English and Old Norse Versions of the Prose Phoenix". Arkiv för Nordisk Filologi 122: 137-156.

Pons-Sanz, Sara M. 2013. The Lexical Effects of Anglo-Scandinavian Linguistic Contact on Old English. Turnhout: Brepols.

Poole, Russell. 2013. “Crossing the Language Divide: Anglo-Scandinavian Language and Literature”. In: Clare A. Lees (ed.). The Cambridge History of Early Medieval English Literature. Cambridge: Cambridge University Press. 530-553.

Pulliam, Heather. 2013. "Beasts of the Desert: Marginalia in the Book of Deer”. Medieval Archaeology 57: 83-110.

Ross, Alan S. C. 1979. “Lindisfarne and Rushworth One”. Notes \& Queries 26: 194-198.

Schaff, Philip (ed.). 1888. A Select Library of the Nicene and Post-Nicene Fathers. Volume 10: St. Chrysostom: Homilies on the Gospel of Saint Matthew. Edinburgh: Clark. <http://www. ccel.org/ccel/schaff/npnf110.pdf>.

Scheck, Thomas P. (trans.). 2008. Commentary on Matthew. Washington, D.C.: The Catholic University of America Press.

Seip, Didrik Arup. 1949. The Arna-Magnæan Manuscript 677, 4to: Pseudo-Cyprian Fragments, Prosper's Epigrams, Gregory's Homilies and Dialogues. Copenhagen: Munksgaard.

Sigurðsson, Páll. 1978. Próun og Pýðing Eiðs og Heitvinningar i Réttarfari. Reykjavík: Háskóli Íslands.

Skeat, Walter (ed.). 1871-1887. The Holy Gospels in Anglo-Saxon, Northumbrian, and Old Mercian Versions, Synoptically Arranged with Collations Exhibiting all the Readings of all the MSS.; together with the Early Latin Version as Contained in the Lindisfarne MS., Collated with the Latin Version in the Rushworth MS. Cambridge: Cambridge University Press.

Stanton, Robert. 2002. The Culture of Translation in Anglo-Saxon England. Cambridge: Brewer. 
Stein-Wilkeshuis, Martina. 2002. "Scandinavians Swearing Oaths in Tenth-Century Russia: Pagans and Christians". Journal of Medieval History 28: 155-168.

Tamoto, Kenichi (ed.). 2013. The Macregol Gospels or The Rushworth Gospels: Edition of the Latin Text with the Old English Interlinear Gloss Transcribed from Oxford Bodleian Library, MS Auctarium D.2.19. Amsterdam: Benjamins.

Taranger, Absalon. 1890. Den Angelsaksiske Kirkes Indflydelse paa den Norske. Kristiania: Grøndahl \& Søns Bogtrykkeri.

Taylor, Arnold R. 1969. “Hauksbók and Alfric’s De Falsis Diis”. Leeds Studies in English 3: 101-109.

Thors, Carl-Eric. 1957. Den Kristna Terminologien i Fornsvenskan. Helsingfors: Svenska Litteratursallskapet i Finland.

Townend, Matthew. 2002. Language and History in Viking Age England: Linguistic Relations between Speakers of Old Norse and Old English. Turnhout: Brepols.

Townend, Matthew. 2005. "Knútr and the Cult of St Óláfr: Poetry and Patronage in EleventhCentury Norway and England". Viking and Medieval Scandinavia 1: 251-279.

Townend, Matthew. 2011. "Cnut's Poets: An Old Norse Literary Community in Eleventh-Century England”. In: Elizabeth M. Tyler (ed.). Conceptualising Multilingualism in England, c.8001250. Turnhout: Brepols. 197-216.

Townend, Matthew. 2013. "Scandinavian Place-Names in England”. In: Jayne Carroll and David N. Parsons (eds.). Perceptions of Place: Twenty-First Century Interpretations of English Place-Name Studies. Nottingham: English Place-Name Society.

Vídalín, Páll. 1854. Skýringar yfir Fornyrði Lögbókar. Reykjavík: Einarr Pórðarson.

Walter, Ernst. 1976. Lexikalisches Lehngut im Altwestnordischen. Berlin: Akademie-Verlag.

Walter, Ernst. 1986. "Die Wiedergabe einiger weltlicher Standes- und Berufsbezeichnungen in der frühen lateinisch-altwestnordischen Übersetzungsliteratur." In: Rudolf Simek, Jónas Kristjánsson, and Hans Bekker-Nielson (eds.). Sagaskemmtun: Studies in Honour of Hermann Pálsson. Wien: Böhlau. 297-308.

Wellendorf, Jonas. 2018. Gods and Humans in Medieval Scandinavia: Retying the Bonds. Cambridge: Cambridge University Press.

Wisén, Theodor (ed.). 1872. Isländska Homilier. Lund: Gleerups Förlag.

Wright, Charles D. 2016. "Jewish Magic and Christian Miracle in the Old English Andreas". In: Samantha Zacher (ed.). Imagining the Jew in Anglo-Saxon Literature. Toronto: University of Toronto Press. 167-193. 